\title{
EFeito do Consórcio de Milho CoM Panicum maximum NA Comunidade Infestante e na Cultura da SoJA Em Rotação
}

\author{
Effect of Corn and Panicum maximum Intercropping on Weed and Soybean Crop in Rotation
}

\author{
CORREIA, N.M..$^{2}$, LEITE, M.B. ${ }^{3}$ e DANIEL, B. ${ }^{3}$
}

\begin{abstract}
RESUMO - Objetivou-se com este trabalho estudar os efeitos do consórcio de milho com colonião (Panicum maximum cv. Aruana) na infestação de plantas daninhas e na cultura da soja em rotação. O experimento foi realizado em campo, no periodo de dezembro de 2008 a abril de 2010, em área experimental da UNESP, campus de Jaboticabal-SP. Utilizou-se o delineamento em blocos ao acaso, com quatro repetições, em esquema de parcela subdividida. Foram estudadas duas formas de semeadura (a lanço e em linha) de colonião nas parcelas e quatro quantidades de sementes (200, 400, 600 e 800 pontos de valor cultural - PVC) nas subparcelas, além de três testemunhas, representadas pelo monocultivo das espécies, como tratamentos adicionais. O cultivo consorciado não afetou o desenvolvimento do milho, comparado ao milho solteiro. Embora na colheita do milho houvesse maior matéria seca e densidade de plantas de colonião com a semeadura de 800 PVC, antes da semeadura da soja o acúmulo de massa não diferiu entre os tratamentos de consórcio. Portanto, a semeadura de 200 PVC de sementes de colonião, a lanço ou em linha, foi suficiente para a manutenção de quantidade $\left(9,1 \mathrm{t} \mathrm{ha}^{-1}\right)$ adequada de palha sobre o solo. Antecedendo a semeadura da soja, a infestação de plantas daninhas na testemunha de milho solteiro foi maior do que nos tratamentos de consórcio e nas testemunhas da forrageira solteira (a lanço e em linha). O mesmo foi observado para densidade de plantas daninhas após a instalação da cultura. Os sistemas de consórcio de milho com colonião não interferiram em nenhuma caracteristica avaliada na cultura da soja cultivada em rotação. Da mesma forma, não foi observada diferença entre os tratamentos de consórcios e a testemunha de milho em monocultivo para produção de grãos de soja.
\end{abstract}

Palavras-chave: Glycine max, integração agricultura-pecuária, plantio direto, Zea mays.

\begin{abstract}
This work aimed to study the effects of corn and colonião grass (Panicum maximum cv Aruana) intercropping on weed infestation and soybean crop in rotation. This research was carried out under field conditions from December 2008 to April 2010 at the UNESP Campus of Jaboticabal, São Paulo, Brazil. The experiment was arranged in a randomized block design in split-plots, with four replications. Two forms of sowing (hand-sowing and on-line sowing) of colonião grass and four amounts of seeds $(200,400,600$, and 800 points of cultural value-PCV) were studied, plus three additional treatments with the single species. Intercropping did not affect vegetative growth and corn yield, when compared to single corn. In the harvest of corn grains, there was more dry matter and plant density of colonião grass when 800 PCV were sown. However, before soybean sowing, dry matter production did not differ between the intercropping treatments. Thus, the sowing of 200 PCV of colonião seeds, hand-sowing and on-line sowing, was sufficient to maintain an adequate amount (9.1 ton ha $\mathrm{a}^{-1}$ ) of mulch on the soil. Priorto soybean sowing, weed infestation in the single corn treatment was higher than during intercropping and the single forage treatment (hand sowing and on-line sowing). The same was observed after the installation of the crop for weed density. Corn and colonião grass intercropping did not influence the characteristics evaluated in the soybean crop cultivated in rotation. No difference was observed between intercropping and corn in monoculture for soybean yield.
\end{abstract}

Keywords: Glycine max, crop-livestock integration, no-tillage, Zea mays.

1 Recebido para publicação em 13.9.2010 e aprovado em 7.12.2010.

2 Professor, Dr., Dep. de Fitossanidade, Universidade Estadual Paulista Júlio de Mesquita Filho - UNESP, Campus de Jaboticabal-SP, Via de Acesso Prof. Paulo Donato Castellane, s/n., 14884-900 Jaboticabal-SP,<correianm@fcav.unesp.br>; ${ }^{3}$ Aluno do curso de graduação em Agronomia, UNESP, Campus de Jaboticabal-SP.

Planta Daninha, Viçosa-MG, v. 29, n. 3, p. 545-555, 2011 


\section{INTRODUÇÃO}

O sistema de consórcio de culturas de grãos com espécies forrageiras possibilita o estabelecimento de pastagens e oferta de alimento para o gado na época seca do ano, além da melhora na qualidade física e química do solo e da produção de palha para o plantio direto. A cultura do milho possui características favoráveis para o cultivo consorciado, como alto porte das plantas e altura de inserção das espigas, permitindo que a colheita ocorra sem interferência das plantas forrageiras (Alvarenga et al., 2006). Além disso, o sistema de produção de consórcio com a cul-tura do milho, em geral, reduz a infestação e suprime o acúmulo de matéria seca de plantas daninhas (Heinrichs et al., 2005; Severino et al., 2006a; Borghi et al., 2008).

Espécies dos gêneros Panicum, por apresentarem sistema radicular vigoroso e profundo, possuem elevada tolerância à deficiência hídrica e absorção de nutrientes em camadas mais profundas do solo, desenvolvendo-se em condições ambientais desfavoráveis para a maioria das culturas produtoras de grãos e de espécies utilizadas para cobertura do solo (Barducci et al., 2009). Por isso, essas espécies constituem-se em excelentes opções para o consórcio com a cultura do milho. A esse re-peito, Severino et al. $(2005,2006 a)$ verificaram que no sistema de consórcio de milho com P. maximum houve maior produção de grãos e as plantas dessa espécie acumularam maior matéria fresca do que as de Brachiaria decumbens e B. brizantha. Esse fato pode ser explicado pela forma de crescimento cespitoso da planta, que forma densas touceiras (Kissmann \& Groth, 1997).

Algumas dúvidas ainda se fazem pertinentes e precisam ser esclarecidas, como o arranjo de semeadura e o estabelecimento de P. maximum em consórcio com a cultura do milho. A semeadura a lanço e em linha junto com o adubo nitrogenado em cobertura são técnicas simples e mais acessiveis aos produtores. Entretanto, a quantidade de sementes deve ser ajustada para cada modalidade de semeadura e estipulada em função do seu valor cultural. Para facilidade na difusão das informações, os valores devem ser expressos em pontos de valor cultural $(\mathrm{PVC}=$ quantidade de sementes $\mathrm{x}$ valor cultural). Nesse contexto, tem-se a região nordeste do Estado de São Paulo, que apresenta dificuldade para o estabelecimento de culturas no outono-inverno, em razão da escassez hídrica, o que interfere na formação de palha para o sistema de plantio direto.

Com base na hipótese de que o cultivo consorciado de milho com colonião não interfere negativamente na produção de grãos de milho, porém pode afetar a infestação de plantas daninhas e fornecer quantidade adequada de palha para a instalação da cultura da soja em rotação, além de beneficiar o desenvolvimento desta, foi realizado o presente traba1ho. Assim, objetivou-se estudar os efeitos do consórcio de milho com colonião (Panicum maximum cv. Aruana) na infestação de plantas daninhas e na cultura da soja em rotação.

\section{MATERIAL E MÉTODOS}

O experimento foi desenvolvido em campo, no período de dezembro de 2008 a abril de 2009, em área experimental da UNESP, campus de Jaboticabal - SP. Ele consistiu de duas fases: na primeira, com início em dezembro de 2008 e término em outubro de 2009, foram estudados os consórcios e a sua influência na cultura do milho e na comunidade infestante; e na segunda (de novembro de 2009 a abril de 2010), foi avaliada a cultura da soja em rotação.

Utilizou-se o delineamento experimental de blocos ao acaso, com quatro repetições, em esquema de parcela subdividida. Foram estudadas duas formas de semeadura (a lanço e em linha) de colonião ( $P$. maximum $\mathrm{cv}$. Aruana) nas parcelas, quatro quantidades de sementes $(200,400,600$ e 800 pontos de valor cultural) nas subparcelas e três testemunhas, representadas pelo monocultivo das espécies, como tratamentos adicionais.

As sementes de colonião apresentavam $80 \%$ de germinação, $90,1 \%$ de pureza e 72,08 de valor cultural.

As parcelas foram constituídas de $3,6 \mathrm{~m}$ de largura e $32 \mathrm{~m}$ de comprimento, e as subparcelas, de 3,6 m de largura e $8 \mathrm{~m}$ de comprimento, com duas linhas centrais e $6 \mathrm{~m}$ de comprimento como área útil, totalizando $10,8 \mathrm{~m}^{2}$. 
O milho (híbrido DKB 350 YG) foi semeado em 18/12/2008, sob preparo convencional do solo, a uma profundidade de $5 \mathrm{~cm}$, com $0,90 \mathrm{~m}$ de distância entre linhas e seis sementes por metro. Com base na análise do solo $(\mathrm{pH}$ em $\mathrm{CaCl}_{2}$ de 5,6; CTC, soma de bases, $\mathrm{H}+\mathrm{Al}$, Ca, $\mathrm{Mg}$ e K de 48, 32, 16, 20, 10 e 3,0 $\mathrm{mmol}_{\mathrm{c}} \mathrm{dm}^{-3}$, respectivamente; $25 \mathrm{~g} \mathrm{dm}^{-3}$ de matéria orgânica; e $27 \mathrm{mg} \mathrm{dm}^{-3}$ de P) e na necessidade nutricional da cultura, foram aplicados $450 \mathrm{~kg} \mathrm{ha}^{-1}$ de 8-24-12 no sulco de semeadura. As sementes foram tratadas com inseticidas (deltamethrin e pirimifos-metil) e fungicidas (fludioxonil e metalaxyl), para proteção de pragas e doenças iniciais.

Para controle de plantas daninhas, os herbicidas nicosulfuron (40 $\left.\mathrm{g} \mathrm{ha}^{-1}\right)$ e 2,4-D (806 $\mathrm{g} \mathrm{ha}^{-1}$ ) foram aplicados em pós-emergência aos 18 dias após a semeadura (DAS).

Aos 23 DAS, as plantas de milho receberam a adubação nitrogenada em cobertura, na quantidade de $75 \mathrm{~kg} \mathrm{ha}^{-1}$ de nitrogênio na forma de sulfato de amônio. Juntamente com esse procedimento, foi semeado o colonião.

O adubo foi distribuído em linha, sem incorporação, com o auxílio de uma adubadora manual. Para melhorar a incorporação, como ocorre no campo com as adubadoras mecanizadas, antes da aplicação, foi feito um sulco superficial (de até $3 \mathrm{~cm}$ de profundidade) no centro de cada entrelinha do milho, utilizandose uma enxadinha de jardim, onde o adubo foi aplicado. Na semeadura em linha, as sementes foram semeadas manualmente sobre o adubo. Já na semeadura a lanço, as sementes foram esparramadas manualmente nas entrelinhas do milho anteriormente à adubação em cobertura.

Aos 31 dias após a semeadura de colonião $\left(\mathrm{DAS}_{\mathrm{C}}\right)$, foi determinada a altura e a matéria seca da parte aérea das plantas de milho. A produção de grãos, o número de plantas por parcela, o número de espigas por planta e por parcela e a massa de 400 grãos foram avaliados no fim do ciclo da cultura (10/4/2009).

$\mathrm{O}$ estande das plantas de colonião foi quantificado aos 31 DAS $_{\mathrm{C}}$ e antes da colheita do milho, por meio da contagem de plantas em duas áreas de $0,45 \mathrm{~m}^{2}$, amostradas aleatoriamente dentro da área útil da subparcela. Antes da colheita do milho e aos 284 DAS $_{C}$
(21/10/2009), 57 dias antes da semeadura da soja, foi feita a coleta da parte aérea das plantas em duas áreas de $0,45 \mathrm{~m}^{2}$, amostradas aleatoriamente dentro da área útil de cada subparcela, para determinação da matéria seca da parte aérea das plantas de colonião.

No fim do ciclo do milho, as plantas daninhas, em duas áreas de $0,45 \mathrm{~m}^{2}$, amostradas aleatoriamente dentro da área útil de cada subparcela, tiveram a parte aérea coletada e levada para secagem em estufa até massa constante. Aos 286 DAS $_{\mathrm{C}}$ (23/10/2009), 55 dias antes da semeadura da soja, foi realizada a avaliação visual de infestação da comunidade infestante, atribuindo-se notas de 0 a $100 \%$, em que 0 representa a ausência de plantas e 100 a cobertura total da subparcela pelas plantas.

Na segunda fase do trabalho, aos 54 dias antes da semeadura da soja, as plantas da área experimental foram roçadas, com o auxílio do equipamento denominado Triton, para uniformizar a cobertura morta nas subparcelas, facilitar a semeadura da soja e beneficiar o controle químico da rebrota das plantas de colonião.

As plantas presentes na área experimental foram dessecadas aos 17 dias antes da semeadura da soja. Utilizou-se a aplicação sequencial de $1,30+0,975 \mathrm{~kg} \mathrm{ha}^{-1}$ de equivalente ácido de glyphosate.

A soja (cv. NK 7059) foi semeada em 19/ $12 / 2010$, no sistema de semeadura direta, a uma profundidade de $5 \mathrm{~cm}$, com $45 \mathrm{~cm}$ de distância entre linhas e 21,4 sementes por metro. A adubação consistiu da aplicação de $245 \mathrm{~kg} \mathrm{ha}^{-1}$ de 02-20-20 no sulco de semeadura. As sementes foram tratadas com o inoculante liquido Masterfix ${ }^{\circledast} \mathrm{L}$, na quantidade de $3,5 \mathrm{~mL} \mathrm{~kg}^{-1}$ de sementes de soja.

$\mathrm{O}$ experimento foi instalado seguindo-se a mesma disposição das parcelas (espécies forrageiras) e subparcelas (quantidades de sementes) do experimento do ano agrícola anterior. As parcelas foram constituidas de 3,6 $\mathrm{m}$ de largura e $32 \mathrm{~m}$ de comprimento, e as subparcelas, de $3,6 \mathrm{~m}$ de largura e $8 \mathrm{~m}$ de comprimento, com três linhas centrais e $6 \mathrm{~m}$ de comprimento como área útil, totalizando $8,1 \mathrm{~m}^{2}$. As cinco linhas de soja foram se-meadas no centro das parcelas, ocupando 2,25 m de largura.

Planta Daninha, Viçosa-MG, v. 29, n. 3, p. 545-555, 2011 
Os herbicidas glyphosate $\left(0,975 \mathrm{~kg} \mathrm{ha}^{-1}\right) \mathrm{e}$ chlorimuron-ethyl (20 $\left.\mathrm{g} \mathrm{ha}^{-1}\right)$ foram aplicados aos 31 dias após a semeadura da soja $\left(\mathrm{DAS}_{\mathrm{S}}\right)$, quando as plantas de soja tinham o quarto trifólio totalmente expandido e as plantas daninhas, de 2 a 10 folhas definitivas (para as dicotiledôneas) e até 4 perfilhos (para as gramineas). Utilizou-se pulverizador montado tratorizado, munido de barra com 24 bicos de jato plano ("leque") 11003, espaçados de 0,5 m, com consumo de calda equivalente a $250 \mathrm{~L} \mathrm{ha}^{-1}$.

Aos $30 \mathrm{DAS}_{\mathrm{S}}$ da soja foi realizada a contagem do número de plantas daninhas em duas áreas de $0,225 \mathrm{~m}^{2}$, escolhidas aleatoriamente dentro da área útil da subparcela. As plantas tiveram a parte aérea coletada e levada para secagem em estufa até massa constante.

Aos $39 \mathrm{DAS}_{\mathrm{S}}$ foi avaliado o número de plantas de soja da área útil de cada subparcela, para obtenção da população de plantas equivalentes por hectare. Aos $74 \mathrm{DAS}_{\mathrm{S}}$ foi determinada a altura e a matéria seca da parte aérea das plantas. A produtividade de grãos e a massa de 100 grãos foram avaliadas no fim do ciclo da cultura (14/4/2010).

Os dados obtidos nas duas fases do estudo foram submetidos ao teste $\mathrm{F}$ da análise de variância. Os efeitos das formas de semeadura, quando significativos, foram comparados pelo teste de Tukey a 5\% de probabilidade, e os das quantidades de sementes, por ajuste polinomial dos dados. Para avaliar o comportamento das testemunhas solteiras (não consorciada) em relação às formas de semeadura e quantidades de sementes, os graus de liberdade de tratamentos foram desdobrados segundo um esquema de contrastes ortogonais de interesse. As testemunhas foram comparadas aos tratamentos consorciados convenientes. Foi aplicado o teste $\mathrm{F}$ para cada contraste, aceitando-se ou rejeitando-se a hipótese $\mathrm{H}_{0}(\mathrm{Y}=0)$.

\section{RESULTADOS E DISCUSSÃO}

\section{Implicações na cultura do milho}

Não se observou efeito significativo das formas de semeadura em nenhuma característica avaliada nas plantas de milho. As quan-tidades de sementes e a interação forma $\mathrm{x}$ quantidade foram significativas apenas para produção de grãos e número de espigas por hectare, respectivamente.

Por meio da análise de contrastes (Tabela 1), os tratamentos de consórcio não influenciaram no desenvolvimento das plantas de milho, comparado ao tratamento de milho solteiro.

Nos consórcios de milho com $B$. brizantha cv. Marandu e $P$. maximum cv. Mombaça, instalados na semeadura ou na adubação de cobertura, apenas a semeadura simultânea de milho com $P$. maximum comprometeu a produção de grãos (Barducci et al., 2009), possivelmente em virtude do hábito de crescimento vegetativo vigoroso (mais prostrado) dessa forrageira, comparado ao da outra espécie (Pariz et al., 2009). As condições climáticas favoráveis, aliadas ao espaçamento entre linhas, proporcionaram rápido estabelecimento

Tabela 1 - Resultados do teste F da análise por meio de contrastes ortogonais dos tratamentos de consórcio (média) e da testemunha de milho em monocultivo, além dos valores médios de altura e matéria seca de plantas, população de plantas por hectare, número de espigas por hectare, número de espigas por planta, massa de 400 grãos e produção de grãos de milho obtidos para os tratamentos de consórcio e testemunha. Jaboticabal-SP. 2008/2009

\begin{tabular}{|l|c|c|c|c|c|c|c|}
\hline \multicolumn{1}{|c|}{ Contraste ortogonal } & $\begin{array}{c}\text { Altura } \\
(\mathrm{cm})\end{array}$ & $\begin{array}{c}\text { Matéria seca } \\
(\mathrm{g} \text { por planta) }\end{array}$ & $\begin{array}{c}\text { População de } \\
\text { plantas ha }\end{array}$ & $\begin{array}{c}\text { Número de } \\
\text { espigas ha }\end{array}$ & $\begin{array}{c}\text { Número de } \\
\text { espigas por } \\
\text { planta }\end{array}$ & $\begin{array}{c}\text { Massa de } \\
400 \text { grãos }(\mathrm{g})\end{array}$ & $\begin{array}{c}\text { Produção de grãos } \\
(\mathrm{kg} \text { ha }\end{array}$ \\
\hline Monocultivo x cons. lanço & $1,49^{\text {ns }}$ & $1,59^{\text {ns }}$ & $0,08^{\text {ns }}$ & $0,13^{\text {ns }}$ & $0,03^{\text {ns }}$ & $2,05^{\text {ns }}$ & $1,37^{\text {ns }}$ \\
\hline Monocultivo x cons. linha & $0,11^{\text {ns }}$ & $1,03^{\text {ns }}$ & $0,04^{\text {ns }}$ & $0,16^{\text {ns }}$ & $0,01^{\text {ns }}$ & $2,42^{\text {ns }}$ & $2,63^{\text {ns }}$ \\
\hline \multicolumn{7}{|c|}{ Tratamento } & \multicolumn{7}{|c|}{ Valor médio } \\
\hline Consórcio a lanço & 145,35 & 68,64 & $68.402,78$ & $62.152,78$ & 0,91 & 122,71 & $9.446,70$ \\
\hline Consórcio em linha & 149,02 & 70,24 & $68.611,11$ & $62.083,33$ & 0,91 & 122,40 & $9.269,20$ \\
\hline Testemunha monocultivo & 148,25 & 76,85 & $69.166,67$ & $62.777,78$ & 0,91 & 126,28 & $9.905,39$ \\
\hline
\end{tabular}

${ }_{\text {ns }}$ Não significativo pelo teste $\mathrm{F}$. 
e desenvolvimento do colonião, limitando a absorção de água, luz e nutrientes pelas plantas de milho, o que refletiu na produtividade da cultura (Barducci et al., 2009). Pariz et al (2009) também relataram que no consórcio de milho com $P$. maximum cv. Mombaça, semeados simultaneamente, houve menor produção de grãos, em razão da competição ocasionada pela forrageira. No entanto, as espécies $P$. maximum cv. Tanzânia e B. ruziziensis não comprometeram a produção de grãos.

No presente trabalho, o colonião foi instalado após a semeadura da cultura principal, o que pode ter desfavorecido a sua interferência no milho, porém o estabelecimento inicial da forrageira não foi prejudicado. O potencial competitivo do cultivar de $P$. maximum também deve ser considerado, visto que, como relatado em outros estudos com Mombaça e Tanzânia, há diferenças entre eles. Possivelmente, o cultivar Aruana possa ser enquadrado no grupo de menor competitividade em sistemas consorciados, similar ao Tanzânia, como foi constatado por Pariz et al. (2009).

Ao desdobrar a interação forma x quantidade, na quantidade de 600 PVC constatouse maior número de espigas de milho por hectare quando o colonião foi semeado em linha; para 200 PVC, as maiores médias ocorreram com a semeadura a lanço; e com 400 e 800 PVC, não houve diferença significativa entre as formas de semeadura (Tabela 2). Para a semeadura em linha, o número de espigas de milho por hectare não foi influenciado pela quantidade de sementes de colonião, com valor médio de 62.083 (Figura 1). Contudo, para a semeadura a lanço, o melhor ajuste dos dados foi obtido na forma polinomial, com maior número de espigas quando semeados 200 e 800 PVC.

Para produção de grãos, os dados também foram ajustados na forma polinomial, e a maior média ocorreu com a semeadura de 200 PVC (Figura 2). Aumentando-se a densidade de semeadura de colonião, o número de plantas da forrageira aumentou consideravelmente nas parcelas. Possivelmente, nas maiores densidades de plantas, o colonião interferiu na cultura do milho, comprometendo a produção de grãos. Entretanto, essas diferenças não foram significativas em relação ao milho solteiro.

Tabela 2 - Número de espigas (por hectare) de milho em consórcio com colonião semeado a lanço e em linha em diferentes quantidades de sementes. Jaboticabal-SP. 2008/ 2009

\begin{tabular}{|c|c|c|}
\hline \multirow{2}{*}{$\begin{array}{c}\text { Quantidade de semeadura } \\
\text { (PVC por hectare) }\end{array}$} & \multicolumn{2}{|c|}{ Número de espigas (por hectare) } \\
\cline { 2 - 3 } & Lanço & Linha \\
\hline 200 & $65.000,00 \mathrm{~A}^{\underline{1} /}$ & $60.555,56 \mathrm{~B}$ \\
\hline 400 & $59.722,22 \mathrm{~A}$ & $61.111,11 \mathrm{~A}$ \\
\hline 600 & $58.888,89 \mathrm{~B}$ & $63.888,89 \mathrm{~A}$ \\
\hline 800 & $65.000,00 \mathrm{~A}$ & $62.777,78 \mathrm{~A}$ \\
\hline DMS (na linha) & \multicolumn{2}{|c|}{$4.285,53$} \\
\hline
\end{tabular}

${ }^{1 /}$ Com base no teste de Tukey a $5 \%$ de probabilidade, médias seguidas de letra maiúscula, nas linhas, comparam as formas de semeadura dentro de cada quantidade de semente.

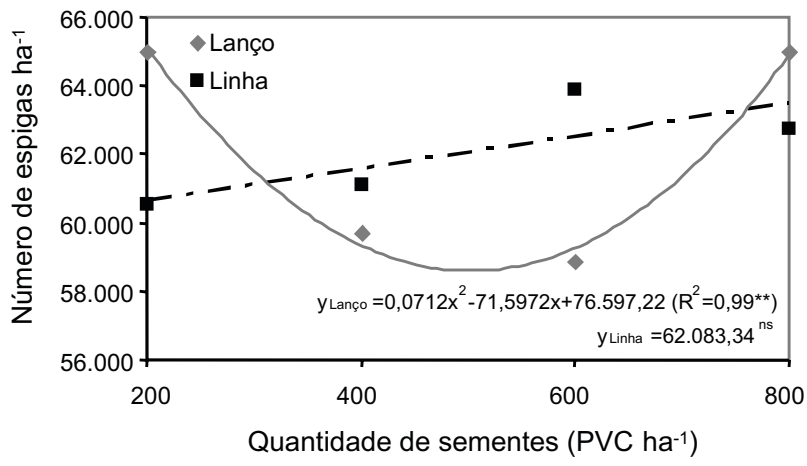

Figura 1 - Número de espigas de milho em consórcio com colonião semeado a lanço e em linha em diferentes quantidades de sementes. Jaboticabal-SP. 2008/2009.

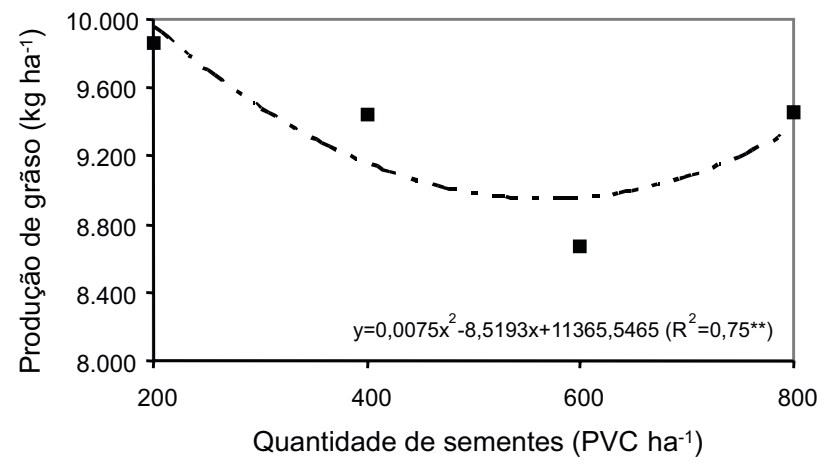

Figura 2 - Produção de grãos de milho em consórcio com colonião semeado em diferentes quantidades de sementes. Jaboticabal-SP. 2008/2009 


\section{Implicações na espécie forrageira}

Não houve efeito significativo das formas de semeadura e da interação forma $x$ quantidade de sementes em nenhuma variável avaliada. As quantidades de sementes influenciaram significativamente o número de plantas aos 31 e 87 dias após a semeadura de colonião $\left(\mathrm{DAS}_{\mathrm{C}}\right)$ e a matéria seca delas aos $87 \mathrm{DAS}_{\mathrm{C}}$.

Por contrastes (Tabela 3), aos $31 \mathrm{DAS}_{\mathrm{C}}$ o número de plantas de colonião nas parcelas das testemunhas solteiras (a lanço e em linha) não diferiu daquele dos tratamentos de consórcio. O mesmo foi observado aos $87 \mathrm{DAS}_{\mathrm{C}}$, exceto para a testemunha de colonião semeado a lanço, que obteve menor média em relação aos tratamentos de consórcio. Para matéria seca da parte aérea, aos 87 DAS $_{C}$ houve maior acúmulo de massa nas plantas das testemunhas solteiras do que nos tratamentos de consórcio. Esse resultado evidencia a grande capacidade competitiva do milho em relação ao colonião quando este foi semeado posteriormente à cultura principal. No entanto, a quantidade de plantas de colonião em cultivo consorciado com milho, aos $87 \mathrm{DAS}_{\mathrm{C}}$, foi estatisticamente similar à das testemunhas em monocultivo. Esse fato favoreceu o pleno estabelecimento da forrageira após a colheita do milho, visto que aos $284 \mathrm{DAS}_{\mathrm{C}}$ as testemunhas de colonião solteiro (em linha e a lanço) não diferiram dos tratamentos de consórcio na produção de matéria seca de plantas, com médias de 11,37, 14,11 e $15,23 \mathrm{t} \mathrm{ha}^{-1}$ para tratamentos de consórcio, testemunhas a lanço e em linha, respectivamente.

As culturas de milho, sorgo, milheto e arroz competiram, em maior ou menor intensidade, com $B$. brizantha estabelecida em consórcio (Portes et al., 2000). Essa competição, essencial para o sucesso do consórcio, resultou em menor número de perfilhos, índice de área foliar e acúmulo de matéria seca de $B$. brizantha consorciada em relação à solteira. Portes et al. (2000) relataram também que a matéria seca de $B$. brizantha solteira aumentou até os 117 dias, atingindo 19,6 t ha-1, estabilizando-se a partir de então. Quando consorciadas com o milho, as plantas alcançaram 2,5 t ha $\mathrm{t}^{-1}$ aos 82 dias, estabilizando o seu crescimento. Cinquenta dias após a colheita do milho, esse valor foi de $4,0 \mathrm{t} \mathrm{ha}^{-1}$. Nesse trabalho, as sementes de $B$. brizantha foram misturadas ao adubo e semeadas a $10 \mathrm{~cm}$ de profundidade no sulco de semeadura do milho.

Leonel et al. (2009) constataram que a produção de forragem para silagem não diferiu entre os tratamentos de milho solteiro, milho com duas linhas de $B$. brizantha na entrelinha e milho com $B$. brizantha semeada a lanço na entrelinha, porém foi superior à de $B$. brizantha em cultivo solteiro. A similaridade da produção das culturas em consórcio e entre essas culturas e o milho solteiro foi devido à baixa produção de massa de $B$. brizantha

Tabela 3 - Resultados do teste F da análise por meio de contrastes ortogonais dos tratamentos de consórcio (média) e das testemunhas do monocultivo a lanço e em linha da espécie forrageira, além dos valores médios do número de plantas de colonião aos 31 e 87 dias após a semeadura $\left(\mathrm{DAS}_{\mathrm{C}}\right.$ ) da espécie forrageira em consórcio com a cultura do milho e para matéria seca das plantas aos $87 \mathrm{e}$

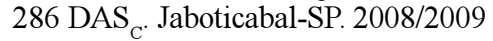

\begin{tabular}{|c|c|c|c|c|}
\hline \multirow[t]{2}{*}{ Contraste ortogonal } & \multicolumn{2}{|c|}{$\begin{array}{l}\text { Número de plantas } \\
\left(\text { por } \mathrm{m}^{2}\right)-\mathrm{DAS}_{\mathrm{C}}\end{array}$} & \multicolumn{2}{|c|}{ Matéria seca - $\mathrm{DAS}_{\mathrm{C}}$} \\
\hline & 31 & 87 & $87\left(\mathrm{~g} \mathrm{~m}^{-2}\right)$ & $284\left(\mathrm{~kg} \mathrm{ha}^{-1}\right)$ \\
\hline Colonião lanço x consórcio & $0,60^{\text {ns }}$ & $5,47^{*}$ & $39,42 * *$ & $0,74^{\mathrm{ns}}$ \\
\hline Colonião linha $\mathrm{x}$ consórcio & $0,54^{\mathrm{ns}}$ & $3,12^{\text {ns }}$ & $73,54 * *$ & $9,27^{\mathrm{ns}}$ \\
\hline Colonião lanço x colonião linha & $0,01^{\mathrm{ns}}$ & $0,18^{\mathrm{ns}}$ & $2,97^{\mathrm{ns}}$ & $2,69^{\text {ns }}$ \\
\hline Tratamento & \multicolumn{4}{|c|}{ Valor médio } \\
\hline Tratamentos de consórcio & 20,80 & 21,22 & 3,88 & $11.317,64$ \\
\hline Colonião lanço & 26,39 & 4,17 & 209,85 & $14.114,30$ \\
\hline Colonião linha & 26,11 & 8,33 & 285,20 & $15.227,20$ \\
\hline
\end{tabular}

${ }^{\text {ns }}$ Não significativo pelo teste $\mathrm{F}$ da análise de variância; **, * Significativo a 1 e $5 \%$ de probabilidade, respectivamente, pelo teste $\mathrm{F}$. 
nesses consórcios por ocasião do corte (grãos de milho com aproximadamente $30,5 \%$ de matéria seca), em relação à produção total de cada uma das formas de cultivo. Nesse trabalho, a semea-dura de $B$. brizantha ocorreu simultaneamente à do milho, na quantidade de 2 a $3 \mathrm{~kg} \mathrm{ha}^{-1}$ de sementes puras.

A densidade de plantas de colonião aos $31 \mathrm{DAS}_{\mathrm{C}}$ e a matéria seca da parte aérea aos $87 \mathrm{DAS}_{\mathrm{C}}$ aumentaram linearmente com o aumento da quantidade de sementes de colonião nas parcelas; já aos $87 \mathrm{DAS}_{\mathrm{C}}$ o melhor ajuste do número de plantas foi o polinomial (Figuras 3 e 4). Esses resultados indicam que houve maior acúmulo de massa e densidade de plantas com a semeadura de 800 PVC de sementes de colonião.

Embora aos $87 \mathrm{DAS}_{\mathrm{C}}$ tenha sido constatado aumento linear no número de plantas de colonião com o aumento da quantidade de sementes, isso não refletiu no acúmulo de massa aos $284 \mathrm{DAS}_{\mathrm{C}}$. Possivelmente, houve maior acúmulo de matéria seca por planta nas parcelas com menor densidade de plantas, obtendo-se, com isso, uma compensação na produção de matéria seca por área. Portanto, apenas 200 PVC de sementes de colonião, semeadas a lanço ou em linha aos 23 dias após a semeadura do milho, foi suficiente para a manutenção de quantidade adequada de palha sobre o solo - média de 9,1 t ha ${ }^{-1}$.

No trabalho desenvolvido por Freitas et al. (2005) a maior produção de matéria seca de $B$. brizantha ocorreu com a sua semeadura em linha na entrelinha do milho, e a menor, quando semeada a lanço aos 30 dias após a semeadura do milho. Nos dois arranjos de semeadura utilizaram-se 380 PVC de sementes. A semeadura a lanço por volta dos 30 dias após a semeadura do milho é a mais comum realizada pelos produtores. Esse fato é justificado pela maior facilidade e praticidade da semeadura das gramineas forrageiras na implantação do consórcio. No entanto, devese adequar a quantidade correta de sementes ao arranjo de semeadura para o melhor estabelecimento das plantas.

Entre os consórcios estudados por Severino et al. (2006a), as plantas de P. maximum produziram maior matéria fresca $\left(56,3 \mathrm{t} \mathrm{ha}^{-1}\right)$ em relação às de $B$. brizantha $\left(32,6 \mathrm{tha}^{-1}\right) \mathrm{e}$

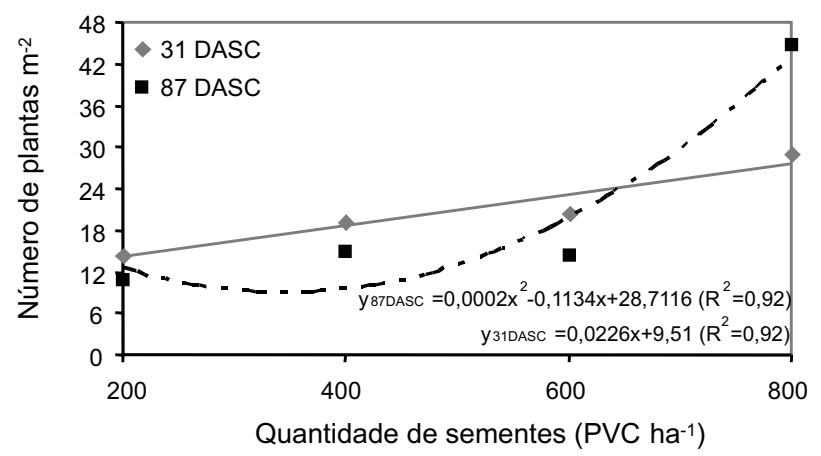

Figura 3 - Número de plantas de capim-colonião aos 31 e 87 dias após a semeadura de diferentes quantidades de sementes da forrageira em consórcio com a cultura do milho. JaboticabalSP. 2008/2009.

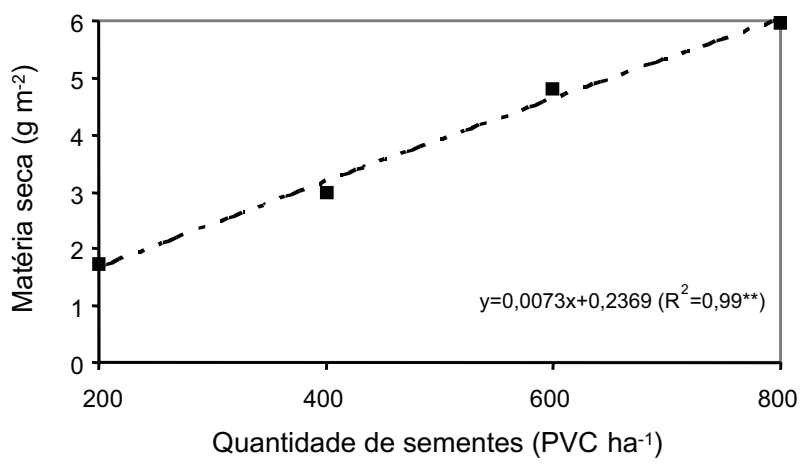

Figura 4 - Matéria seca da parte aérea de capim-colonião aos 87 dias após a semeadura de diferentes quantidades de sementes da forrageira em consórcio com a cultura do milho. Jaboticabal-SP. 2008/2009.

B. decumbens $\left(32,6 \mathrm{t} \mathrm{ha}^{-1}\right)$, sendo as espécies $P$. maximum e $B$. brizantha consideradas boas competidoras nesse sistema de produção.

\section{Implicações nas plantas daninhas}

Os fatores isolados ou a interação destes não afetaram significativamente a matéria seca da parte aérea aos $87 \mathrm{DAS}_{\mathrm{C}}$. Entretanto, aos 286 DAS $_{C}$ houve efeito significativo das quantidades de sementes e da interação forma $x$ quantidade na infestação de plantas daninhas.

Por meio da análise de contrastes (Tabela 4), ao se comparar a testemunha de milho solteiro com os tratamentos de consórcio, não houve diferença entre eles para matéria seca da parte aérea aos $87 \mathrm{DAS}_{\mathrm{C}}$. No 
monocultivo de colonião, as plantas daninhas acumularam maior massa e diferiram significativamente do milho solteiro e dos tratamentos de consórcio. Aos 286 DAS $_{\mathrm{C}}$ houve maior infestação de plantas daninhas na testemunha de milho em monocultivo, em comparação aos tratamentos de consórcio e às testemunhas da forrageira solteira (a lanço e em linha). Isso comprova a interferência do colonião nas plantas daninhas quando estabelecido na entressafra das culturas, no período do outono/inverno.

Experimentos de campo, com produção in locu dos resíduos vegetais, são extremamente complexos, pois se trata do somatório do manejo adotado no período de outono/ inverno, com a manutenção das culturas para produção de palha, e dos efeitos propriamente ditos dessa palha depositada sobre o solo. Uma forma de reduzir a densidade populacional potencial de plantas daninhas em determinada área é evitar a adição de novos diásporos ao solo, conseguida, entre outros manejos, por meio do controle da produção de sementes pela planta no período de outono/inverno. Essa prática é denominada de manejo preventivo na entressafra, com a eliminação das plantas daninhas antes que elas produzam sementes, por meios químicos, mecânicos ou culturais. No presente trabalho, as plantas de colonião, tanto dos tratamentos de consórcio quanto das testemunhas solteiras da forrageira, cobriram rapidamente o solo, impedindo a ocorrência de plantas daninhas, contrariamente ao obser-vado na testemunha de milho solteiro. Nesta, houve altíssima infestação e produção de sementes pelas plantas daninhas, o que aumentou o banco de sementes do solo e, por conseguinte, o potencial de infestações futuras no local.

Em outro trabalho, com a semeadura simultânea das culturas, as três espécies forrageiras testadas $(B$. decumbens, $B$. brizantha e $P$. maximum), juntamente com os efeitos promovidos pela cultura do milho, suprimiram a densidade de Ipomoea grandifolia, Amaranthus hybridus e Digitaria horizontalis nas parcelas, exceto $B$. decumbens para I. grandifolia, cuja infestação não diferenciou daquela da testemunha. O melhor resultado na supressão dessa espécie foi obtido com $B$. brizantha (Severino et al., 2006b). A semeadura de milho e das espécies forrageiras no mesmo dia pode conferir às plantas forrageiras maior capa-cidade de supressão das plantas daninhas, devido à rápida ocupação do nicho ecológico pelas forrageiras e, consequentemente, à diminuição dos recursos necessários ao crescimento e desenvolvimento das plantas daninhas (Severino et al., 2006a).

Tabela 4 - Resultados do teste F da análise por meio de contrastes ortogonais dos tratamentos de consórcio (média) e das testemunhas do milho e da espécie forrageira semeada a lanço e em linha em monocultivo, além dos valores médios da porcentagem de infestação aos 31 e 286 dias após a semeadura $\left(\mathrm{DAS}_{\mathrm{C}}\right)$ de colonião e matéria seca da parte aérea de plantas daninhas aos $87 \mathrm{DAS}_{\mathrm{C}}$, no cultivo consorciado de milho com colonião. Jaboticabal-SP. 2008/2009

\begin{tabular}{|l|c|c|c|}
\hline \multirow{2}{*}{ Contraste ortogonal } & \multicolumn{2}{c|}{ Infestação (\%) - DAS } & \multirow{2}{*}{$\begin{array}{c}\text { Matéria seca } \\
\left(\mathrm{g} \mathrm{m}^{-2}\right)\end{array}$} \\
\cline { 2 - 4 } & 31 & 286 & $0,01^{\mathrm{ns}}$ \\
\hline Milho x consórcio & $0,09^{\mathrm{ns}}$ & $529,59^{* *}$ & $74,40^{* *}$ \\
\hline Colonião lanço x consórcio & $0,82^{\mathrm{ns}}$ & $0,34^{\mathrm{ns}}$ & $48,26^{* *}$ \\
\hline Colonião linha x consórcio & $0,57^{\mathrm{ns}}$ & $0,43^{\mathrm{ns}}$ & $42,43^{* *}$ \\
\hline Milho x colonião lanço & $0,21^{\mathrm{ns}}$ & $313,14^{* *}$ & $27,62^{* *}$ \\
\hline Milho x colonião linha & $0,12^{\mathrm{ns}}$ & $315,12^{* *}$ & $1,59^{\mathrm{ns}}$ \\
\hline Colonião lanço x colonião linha & $0,01^{\mathrm{ns}}$ & $0,00^{\mathrm{ns}}$ & \multicolumn{2}{c|}{18,99} \\
\hline \multicolumn{1}{|c|}{ Tratamento } & \multicolumn{2}{|c|}{ Valor médio $^{2}$} \\
\hline Tratamentos de consórcio & 18,75 & 2,20 & 17,98 \\
\hline Monocultivo milho & 20,00 & 79,50 & 164,20 \\
\hline Monocultivo colonião lanço & 22,50 & 0,25 & 135,93 \\
\hline Monocultivo colonião linha & 21,88 & 0,00 & \\
\hline
\end{tabular}

${ }^{\text {ns }}$ Não significativo pelo teste $\mathrm{F}$ da análise de variância; ${ }^{* *}$ Significativo a $1 \%$ de probabilidade pelo teste $\mathrm{F}$. 
Aos $286 \mathrm{DAS}_{\mathrm{C}}$, na densidade de 200 PVC constatou-se maior infestação de plantas daninhas quando o colonião foi semeado a lanço (Tabela 5). Contudo, para as demais densidades de semeadura não houve diferença significativa entre as formas de semeadura. Para a semeadura em linha, a infestação de plantas daninhas não foi influenciada pela quantidade de sementes de colonião, com valor médio de 1,94\% (Figura 5). Entretanto, para a semeadura a lanço, o melhor ajuste dos dados foi obtido na forma polinomial, com maior porcentagem de ocorrência de plantas daninhas quando semeados 200 PVC.

Na cultura da soja em rotação, os sistemas de consórcio de milho com colonião estudados no primeiro ano do trabalho não diferiram entre si para densidade de plantas daninhas e matéria seca da parte aérea. Por outro lado, com base na análise por meio de contrastes (Tabela 6), verificou-se menor número de plantas daninhas nos tratamentos de consórcio (semeadura a lanço e em linha) do que na testemunha de milho em monocultivo.

\section{Implicações na cultura da soja em rotação}

Os sistemas de consórcio de milho com colonião avaliados no primeiro ano do estudo não diferiram entre si para nenhuma característica avaliada na cultura da soja semeada em rotação. Esse resultado é explicado, possivelmente, pela uniformidade de cobertura do solo pelo colonião no período de

Tabela 5 - Infestação de plantas daninhas (\%) aos 286 dias após a semeadura de colonião a lanço e em linha em diferentes quantidades de sementes em consórcio com a cultura do milho. Jaboticabal-SP. 2008/2009

\begin{tabular}{|c|l|c|}
\hline \multirow{2}{*}{$\begin{array}{c}\text { Quantidade de semeadura } \\
\text { (PVC por hectare) }\end{array}$} & \multicolumn{2}{|c|}{ Infestação (\%) } \\
\cline { 2 - 3 } & Lanço & Linha \\
\hline 200 & $6,88 \mathrm{~B}^{\underline{1}}$ & $3,00 \mathrm{~A}$ \\
\hline 400 & $0,25 \mathrm{~A}$ & $2,00 \mathrm{~A}$ \\
\hline 600 & $1,00 \mathrm{~A}$ & $1,50 \mathrm{~A}$ \\
\hline 800 & $1,75 \mathrm{~A}$ & $1,25 \mathrm{~A}$ \\
\hline DMS (na linha) & \multicolumn{2}{|c}{2,04} \\
\hline
\end{tabular}

1/ Com base no teste de Tukey a $5 \%$ de probabilidade, médias seguidas de letra maiúscula, nas linhas, comparam as formas de semeadura dentro de cada quantidade de semente.

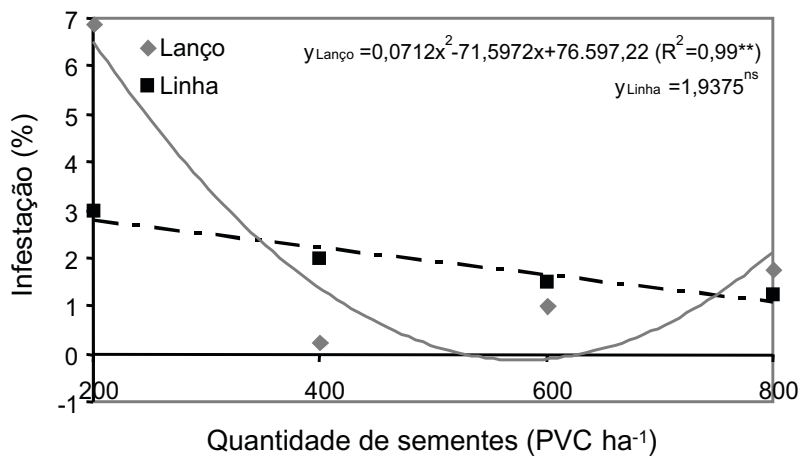

Figura 5 - Infestação de plantas daninhas aos 286 dias após a semeadura de colonião a lanço e em linha em diferentes quantidades de sementes em consórcio com a cultura do milho. Jaboticabal-SP. 2008/2009.

outono/inverno, mesmo variando a forma e a densidade de semeadura da forrageira. Apesar das diferenças observadas na densidade de plantas de colonião antes da colheita do milho, a quantidade de palha mantida sobre o solo, 57 dias antes da semeadura da soja, não diferiu entre os tratamentos de consórcio estudados.

Por meio de contrastes ortogonais (Tabela 6), verificou-se que as plantas de soja da testemunha de milho solteiro tiveram maior matéria seca e altura em relação às plantas dos tratamentos de consórcio de colonião semeado a lanço. No entanto, esses resultados não se refletiram na produção de grãos de soja, pois os tratamentos de consórcios não diferiram da testemunha de milho em monocultivo.

Pacheco et al. (2009) verificaram que o estande, o número de vagens com dois e três grãos e a massa de mil grãos de soja cultivada sobre palha de diferentes plantas de cobertura praticamente não tiveram alterações. Contudo, a produção de grãos foi influenciada pela presença de palha na superfície do solo, obtendo-se maior produtividade sobre cobertura de $B$. ruziziensis, comparada à da testemunha sem plantas de cobertura (pousio). Em outro trabalho, as plantas de soja crescidas sobre cobertura morta de Brachiaria brizantha (nos dois anos do estudo) e de Eleusine coracana (no segundo ano) tiveram maior produção de grãos, matéria seca da parte aérea e altura de plantas do que as plantas da testemunha (Correia \& Durigan, 2006). Nunes et al. (2006) 
Tabela 6 - Resultados do teste F por meio de contrastes ortogonais dos tratamentos de consórcio (média) e das testemunhas de milho e colonião em monocultivo, além dos valores médios das variáveis avaliadas na comunidade infestante (número de plantas, matéria seca da parte aérea e matéria seca por planta) e na cultura de soja (população de plantas por hectare, matéria seca da parte aérea, altura, massa de 100 grãos e produção de grãos) estabelecida em rotação com consórcio de milho com colonião. Jaboticabal-SP. 2009/2010

\begin{tabular}{|c|c|c|c|c|c|c|c|c|}
\hline \multirow[b]{2}{*}{ Fonte de variação } & \multicolumn{3}{|c|}{ Comunidade infestante } & \multicolumn{5}{|c|}{ Soja } \\
\hline & \begin{tabular}{|c|}
$\begin{array}{c}\mathrm{o} \\
\text { de } \\
\text { plantas } \mathrm{m}^{-2}\end{array}$ \\
\end{tabular} & \begin{tabular}{|c|}
$\begin{array}{c}\text { Matéria seca } \\
\left(\mathrm{g} \mathrm{m}^{-2}\right)\end{array}$ \\
\end{tabular} & \begin{tabular}{|c|} 
Matéria seca \\
por planta
\end{tabular} & $\begin{array}{c}\text { População de } \\
\text { plantas ha }^{-1}\end{array}$ & \begin{tabular}{|l|}
$\begin{array}{l}\text { Matéria seca } \\
\text { (g por planta) }\end{array}$ \\
\end{tabular} & $\begin{array}{l}\text { Altura } \\
(\mathrm{cm})\end{array}$ & \begin{tabular}{|c|} 
Massa de \\
100 grãos $(\mathrm{g})$ \\
\end{tabular} & \begin{tabular}{|c|}
$\begin{array}{c}\text { Produção de } \\
\text { grãos }\left(\mathrm{kg} \mathrm{ha}^{-1}\right)\end{array}$ \\
\end{tabular} \\
\hline Monoc. milho $\mathrm{x}$ cons. lanço & $6,88^{*}$ & $0,00^{\text {ns }}$ & $1,49^{\text {ns }}$ & $0,05^{\text {ns }}$ & $4,68^{*}$ & $7,61^{* *}$ & $2,26^{\mathrm{ns}}$ & $0,01^{\mathrm{ns}}$ \\
\hline Monoc. milho $\mathrm{x}$ cons. linha & $7,80 * *$ & $1,06^{\mathrm{ns}}$ & $0,08^{\text {ns }}$ & $0,01^{\mathrm{ns}}$ & $2,19^{\text {ns }}$ & $2,08^{\mathrm{ns}}$ & $0,56^{\mathrm{ns}}$ & $0,04^{\mathrm{ns}}$ \\
\hline Monoc. lanço x cons. lanço & $0,12^{\text {ns }}$ & $2,96^{\mathrm{ns}}$ & $3,61^{\text {ns }}$ & $1,45^{\mathrm{ns}}$ & $1,81^{\mathrm{ns}}$ & $0,00^{\mathrm{ns}}$ & $0,11^{\mathrm{ns}}$ & $4,41^{\mathrm{ns}}$ \\
\hline Monoc. linha $\mathrm{x}$ cons. linha & $0,91^{\text {ns }}$ & $1,35^{\mathrm{ns}}$ & $0,60^{\text {ns }}$ & $0,03^{\text {ns }}$ & $0,58^{\text {ns }}$ & $0,48^{\text {ns }}$ & $3,73^{\text {ns }}$ & $1,90^{\text {ns }}$ \\
\hline Tratamento & \multicolumn{8}{|c|}{ Valor médio } \\
\hline Consórcio a lanço & 204,72 & 31,23 & 0,17 & $297.222,21$ & 19,08 & 45,99 & 12,93 & $2.110,24$ \\
\hline Consórcio em linha & 199,31 & 24,23 & 0,14 & $277.870,36$ & 23,45 & 47,98 & 13,26 & $2.215,51$ \\
\hline Monocultivo milho & 288,33 & 30,97 & 0,12 & $274.814,80$ & 26,17 & 50,15 & 13,58 & $2.138,94$ \\
\hline Monocultivo colonião lanço & 215,56 & 20,00 & 0,09 & $285.185,17$ & 16,73 & 45,95 & 13,07 & $2.372,67$ \\
\hline Monocultivo colonião linha & 168,89 & 16,64 & 0,11 & $288.888,87$ & 24,23 & 46,92 & 12,42 & $2.315,96$ \\
\hline
\end{tabular}

${ }^{\text {ns }}$ Não significativo pelo teste $\mathrm{F} ;{ }^{* *},{ }^{*}$ Significativo a 1 e $5 \%$ de probabilidade, respectivamente, pelo teste $\mathrm{F}$.

constataram que os melhores resultados de massa de 100 sementes e produtividade de feijão foram obtidos sobre palha de $P$. maximum cv. Mombaça, B. brizantha, B. decumbens e P. maximum cv. Tanzânia, estabelecidas em monocultivo antes da cultura de feijão.

O cultivo consorciado de milho com colonião ( $P$. maximum cv. Aruana), semeado a lanço ou em linha aos 23 dias após a semea dura (DAS) do milho, não interferiu na produ ção de grãos da cultura em relação ao milho solteiro. Da mesma forma, o consórcio de milho com colonião no primeiro ano do experimento também não afetou a produção de grãos de soja, em comparação ao milho solteiro.

Embora na colheita do milho houvesse maior matéria seca e densidade de plantas de colonião com a semeadura de 800 PVC, antes da semeadura da soja o acúmulo de massa não diferiu entre os tratamentos de consórcio. Portanto, a semeadura de 200 PVC de sementes de colonião, a lanço ou em linha, aos 23 DAS do milho foi suficiente para a manutenção de quantidade $\left(9,1 \mathrm{t} \mathrm{ha}^{-1}\right)$ adequada de palha sobre o solo. Além disso, antecedendo a semeadura da soja, a infestação de plantas daninhas na testemunha de milho solteiro foi maior em comparação aos tratamentos de consórcio e às testemunhas da forrageira solteira (a lanço e em linha). O mesmo foi observado para densidade de plantas daninhas após a instalação da cultura.

\section{AGRADECIMENTOS}

Ao Conselho Nacional de Desenvolvimento científico e Tecnológico (CNPQ), pelo apoio financeiro.

\section{LITERATURA CITADA}

ALVARENGA, R. C. et al. A cultura do milho na integração lavoura-pecuária. Sete Lagoas: Embrapa Milho e Sorgo, 2006. (Circular Técnica, 80)

BARDUCCI, R. S. et al. Produção de Brachiaria brizantha e Panicum maximum com milho e adubação nitrogenada. Arch. Zootec., v. 58, n. 222, p. 211-222, 2009.

BORGHI, E. et al. Influência da distribuição espacial do milho e da Brachiaria brizantha consorciadas sobre a população de plantas daninhas em sistema de plantio direto na palha. Planta Daninha, v. 26, n. 3, p. 559-568, 2008.

CORREIA, N. M; DURIGAN, J. C. Influência do tipo e quantidade de resíduos vegetais associados a herbicidas residuais no desenvolvimento da cultura da soja. Bragantia, v. 65, p. $421-432,2006$

FREITAS, F. C. L. et al. Formação de pastagem via consórcio de Brachiaria brizantha com o milho para silagem no sistema de plantio direto. Planta Daninha, v. 23, n. 1, p. 49-58, 2005. 
HEINRICHS, R. et al. Características químicas de solo e rendimento de fitomassa de adubos verdes e de grãos de milho, decorrente do cultivo consorciado. R. Bras. Ci. Solo v. 29, n. 1, p. $71-79,2005$.

KISSMANN, K. G; GROTH, D. Plantas infestantes e nocivas. 2.ed. São Paulo: BASF, 1997. Tomo I. 825 p.

LEONEL, F. P. et al. Consórcio capim-braquiária e milho: comportamento produtivo das culturas e características nutricionais e qualitativas das silagens. R. Bras. Zootec., v. 38, n. 1 , p. $166-176,2009$.

NUNES, U. R. et al. Produção de palhada de plantas de cobertura e rendimento do feijão em plantio direto. Pesq. Agropec. Bras., v. 41, n. 6, p. 943-948, 2006.

PACHECO, L. P. et al. Sobressemeadura da soja como técnica para supressão da emergência de plantas daninhas.

Planta Daninha, v. 27, n. 3, p. 455-463, 2009.

PARIZ, C. M. et al. Desempenhos técnicos e econômicos da consorciação de milho com forrageiras dos gêneros Panicum e Brachiaria em sistema de integração lavoura-pecuária. Pesq. Agropec. Tropic., v. 39, n. 4, p. 360-370, 2009.
PORTES, T. D. et al. Análise do crescimento de uma cultivar de braquiária em cultivo solteiro e consorciado com cereais. Pesq. Agropec. Bras., v. 35, n. 7, p. 1349-1358, 2000 .

SEVERINO, F. J.; CARVALHO, S. J. P.; CHRISTOFFOLETI, P. J. Interferências mútuas entre a cultura do milho, espécies forrageiras e plantas daninhas em um sistema de consórcio. I - implicações sobre a cultura do milho (Zea mays). Planta Daninha, v. 23, n. 4, p. 589-596, 2005 .

SEVERINO, F. J.; CARVALHO, S. J. P.; CHRISTOFFOLETI, P. J. Interferências mútuas entre a cultura do milho, espécies forrageiras e plantas daninhas em um sistema de consórcio: II - implicações sobre as espécies forrageiras. Planta Daninha, v. 24, n. 1, p. 45-52, 2006a.

SEVERINO, F. J.; CARVALHO, S. J. P.; CHRISTOFFOLETI, P. J. Interferências mútuas entre a cultura do milho, espécies forrageiras e plantas daninhas em um sistema de consórcio: II - implicações sobre as plantas daninhas. Planta Daninha, v. 24, n. 1, p. 53-60, $2006 b$. 